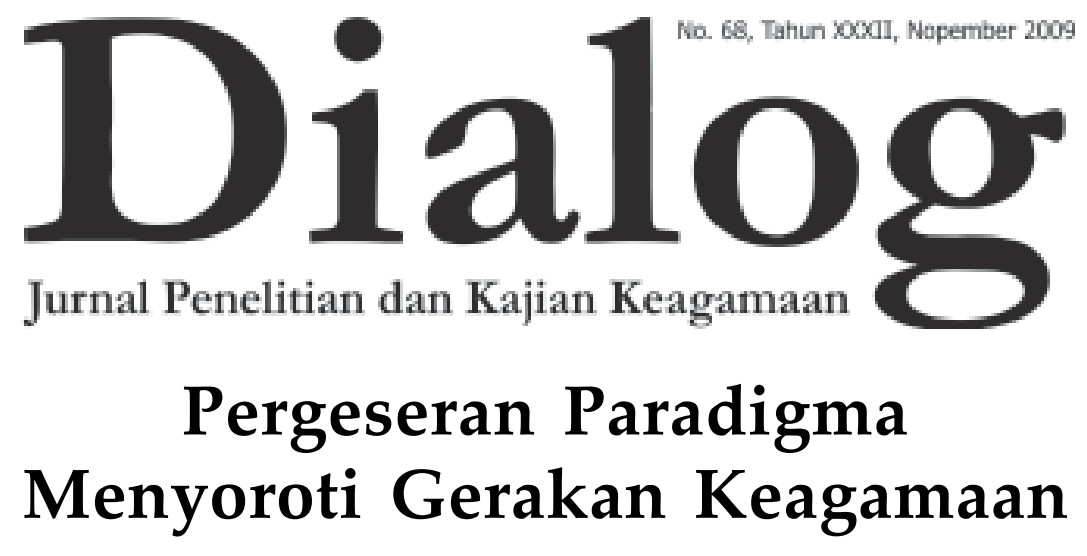




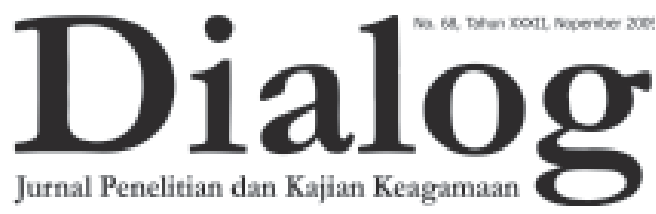

Pemi mpin Umum:

Prof. Dr. H. M. Atho Mudzhar, MA

Redaktur Ahli:

Prof. Dr. H. Nasaruddin Umar, MA

Prof. Dr. H. Komarudin Hidayat, MA

Pemimpin Redaksi / Penanggung J awab

Drs. H. Syamsuddin

Wakil Pemi mpin Redaksi

H. Fanani Suprianto, SH., MM

Sekretaris Redaksi

M. Rosyid Fauzi, S.Si.

Dewan Redaksı

Prof. Dr. H. Abdurrahman Mas'ud Drs. Amin Haedari

Prof. Dr. H. Maidir Harun

Drs. H. Mohammad Shohib, MA

Drs. H. Asmu'i, SH, MM

Chamdi Pamudji, SH., MM

Redaktur Eksekutif

M. Nasir, S.Th.I.

Redaktur Pelaksana

Moh. Rosyid Fauzi, S.Si

M. Nasir, S.Th.I

M. Adlin Sila, M.A

Abbas Jauhari, M.Ag

Administrasi

Drs. Dedy Curipno

Sutidjah

Desriyanti Nasution, S.IPI

Drs. H. Sahlani

Alamat Redaksi

Gedung Bayt Alquran Museum Istiqlal Komplek Taman Mini Indonesia Indah

Telp. (021) 87791444-87794982

Website:

www. balitbangdiklat.depag.go.id

Email:

info@depag.web.id

\section{Pergeseran Paradigma Menyoroti Gerakan Keagamaan}

Fenomena munculnya berbagai aliran keagamaan di Indonesia beberapa tahun terakhir menunjukan kecenderungan positif dalam kebebasan beragama. Namun sayangnya kebebasan menampilkan ekspresi keberagamaan tersebut kerapkali melampaui dari apa yang semestinya. Hal tersebut dapat kita lihat dengan munculnya gerakan keagamaan yang mengusung berbagai macam ajaran, ritual keagamaan yang aneh bahkan cenderung mengancam serta menodai kesucian aqidah, ibadah, ritual, dan pendirian mayoritas ummat yang sudah mapan. Sejak tahun 1989, setidaknya telah ada beberapa aliran keagamaan diberikan label haram oleh MUI (Majelis Ulama Indonesia), diantara aliran yang dianggap menyesatkan itu antara lain: Islam Jama'ah, Ahmadiyah, Ingkar Sunnah, Qur'an Suci, Sholat Dua Bahasa, Lia Eden dan al-Qiyadah al-Islamiyah.

Fenomena ini ditenggarai oleh sebagian pihak sebagai akibat dari kegagalan dakwah. Para da'i dianggap tidak mampu mentransformasikan nilainilai ajaran Islam secara kaffah 
(komprehensif) kepada ummat, dakwah selama ini sering bersifat eksklusif, menghakimi dan memprovokasi. Aktifitas dakwah hanya menampilkan Islam dari aspek langit atau 'ubudiyah (habluminallah) bukan aspek bumi dimana kehidupan sosial (habluminannas) bergulir, sehingga wajar berbagai permasalahan sosial yang dialami ummat tidak tersentuh. Fakta ini menyebabkan ummat mencari solusi lain atas permasalahan sosial yang mereka alami dengan cara "selingkuh" yaitu menganut sekte atau aliran baru dalam sebuah agama yang menawarkan solusi instan, namun cenderung "menyesatkan".

Para da'i, tokoh masyarakat, maupun para pemegang kebijakan ke depan harus mampu merubah paradigma yang selama ini salah dan telah mengkristal di kalangan ummat. Mereka diharapkan tidak berperan sebagai juru dakwah, juru vonis, juru putus, yang hanya menyampaikan pesan bil lisan di atas mimbar saja, tapi lebih dari itu, merek dituntut menjadi -meminjam istilah Clifford Geertz- cultural broker (makelar budaya), bahkan menjadi intermediary forces (kekuatan perantara) bagi permasalahan sosial ummat dalam istilah Hiroko Horikoshi.

Dalam kajian Jurnal Dialog Edisi ini mencoba mengulas tentang Pergeseran Paradigma Menyoroti Gerakan Keagamaan yang kerapkali menghadirkan tematema aktual di tengah-tengah masyarakat. Kajian Jurnal Dialog edisi ini diawali dengan tulisan Prof. Dr. H.M.
Atho Mudzhar tentang Instrumen Internasional dan Peraturan Perundangan Indonesia tentang Kebebasan dan Perlindungan Beragama. Dilanjutkan dengan tulisan Prof. Dr. Abdurrahman Mas'ud yang mengupas tentang Menyikapi Keberadaan Aliran Sempalan.

Sukris Sarmadi, Dosen STAIN Banjarmasin menghadirkan tulisan tentang Transformasi NU dalam Masyarakat Banjar Kini PerspektifPergeseran Gerakan Keagamaan di Kalimantan Selatan. Sedangkan M. Ulinnuha Khusnan, MA melalui tulisannya mencoba memotret Paradigma Keberagamaan Kaum Santri. Nurhasanah dosen UIN Jakarta menghadirkan tulisan tentang Politik Kebijakan Islamisasi Mahathir. Kajian jurnal dialog edisi ini kian lengkap dengan hadirnya tulisan Anwar Mujahidin, MA, tentang Science And Religion (Paradigma Al-Qur'an untuk IlmuIlmu Sosial Menurut Pemikiran Kuntowijoyo).

Di samping memuat artikel ilmiah, Jurnal Dialog edisi ini juga memuat laporan hasil penelitian oleh Ridwan Bustaman, tentang Analisis Wacana Kritis : Tayangan Kekerasan dalam Sinetron Bernuansa Keagamaan. Dan juga hasil penelitian saudara Basuki tentang Pesantren, Tasawufdan Hedonisme Kultural (Studi Kasus Aktualisasi Nilai-nilai Tasawuf dalam Hidup dan Kehidupan di Pondok Pesantren Modern Gontor). Serta hasil penelitian saudari Maryam tentang Interaksi Sosial Pelaku Konversi Agama Etnik Cina.

Kajian ini diakhiri dengan telaah 
buku yang mengulas buku karya Prof. Abdurrahman, 2009 yang berjudul Menebar Rahmat bagi Sekalian Alam. Semoga kajian yang dihadirkan Jurnal Dialog edisi ini memberikan manfaat yang berarti bagi para pembaca, khususnya dalam kajian Pergeseran Paradigma Menyoroti Gerakan Keagamaan. Selamat Membaca!

Redaksi

4 Dialog No. 68, Tahun XXXII, Nopember 2009 
TOPIK

M. Atho Mudzhar

Instrumen Internasional dan Peraturan Perundangan Indonesia tentang Kebebasan dan Perlindungan Beragama - -6

Abdurrahman Mas'ud

Menyikapi Keberadaan Aliran Sempalan --16

SUKRIS SARMADI

Transformasi NU dalam Masyarakat Banjar Kini Perspektif Pergeseran Gerakan Keagamaan di Kalimantan Selatan - 25

\section{Ulinnuha KhuSNAN}

Memotret Paradigma Keberagamaan Kaum Santri —41

\section{NuRHASANAH}

Politik Kebijakan Islamisasi Mahathir —65

\section{Anwar Mujahidin}

Science And Religion (Paradigma Al-Qur'An untuk Ilmu-Ilmu Sosial Menurut Pemikiran Kuntowijoyo) -78

\section{PENELITIAN}

\section{RidWAN Bustamam}

Analisis Wacana Kritis : Tayangan Kekerasan dalam Sinetron Bernuansa Keagamaan $\longrightarrow 97$

\section{BASUKI}

Pesantren, Tasawuf dan Hedonisme Kultural (Studi Kasus Aktualisasi Nilainilai Tasawuf dalam Hidup dan Kehidupan di Pondok Pesantren Modern Gontor) -112

MARYAM

Interaksi Sosial Pelaku Konversi Agama Etnik Cina --135

\section{BOOK REVIEW}

\section{Dewi $\mathbf{N}$}

Menebar Rahmat bagi Sekalian Alam —149 


\title{
Transformasi NU dalam Masyarakat Banjar Kini Perspektif Pergeseran Gerakan Keagamaan di Kalimantan Selatan
}

\author{
OLEH: A.SUKRIS SARMADI*)
}

\begin{abstract}
This article describes the expantion of NUorganization in Banjar community. Particularly, the article explain the history of the foundation of NU as supported by the clan of religious figures in the empire of Banjar that is Big Sheikh Muhammad Arsyad al Banjari. NU become more accepted in the society of Banjar. NU has adopted many elements of local cultures. Moslems in Banjar recognize Islam as a habit of NU culture. The condition of economics and social changes in modern society of Banjar have forced cultural value of NU in the city of Banjarmasin. Pasantren has become the strong bases until now for religious movement of NU.
\end{abstract}

\section{A. Pendahuluan}

Agama Islam merupakan agama mayoritas bagi masyarakat Kalimantan Selatan dengan didominasi suku Banjar berjumlah 2.271.586 Jiwa dari total penduduk Kal-Sel tahun 2000 : 2.975 .440 jiwa (Badan Pusat Statistik - Sensus Penduduk Tahun 2000). Sisanya adalah penduduk pendatang yaitu suku Jawa, Bugis, Madura, Dayak, Mandar, Bakumpai dan lainnya. Kedekatan masyarakat Banjar dengan agama Islam telah lama terjadi di mulai dengan berdirinya Kesultanan Banjar meliputi DAS Barito bagian hilir, DAS Bahan (Negara), DAS Martapura dan DAS Tabanio. Islam masuk di Kal-Sel terjadi pada suku Banjar di mulai dengan

*) Dosen Fakultas Syariah IAIN Antasari Banjarmasin masuk Islamnya Raja Banjar Pangeran Samudera bergelar Sultan Suriansyah (24 September 1526/6 Zulhijjah 932 H). Selanjutnya keturunan kerajaan / kesultanan Banjar dan masyarakat Banjar hingga sekarang beragama Islam. Agama Islam telah lama menjadi ciri masyarakat Banjar dan Islam menjadi agama mayoritas di mana $98 \%$ pendudukanya beragama Islam (Alfani Daud, 1997, h. 5).

Masyarkat Banjar kini ${ }^{1}$ seperti halnya pada umumnya disemua daerah

${ }^{1}$ Berada di Provinsi Kalimantan Selatan dengan nama kota Banjarmasin. Sukubangsa Banjar adalah suku bangsa yang menempati sebagian besar wilayah Provinsi Kalimantan Selatan, sebagian Kalimantan Timur dan sebagian Kalimantan Tengah terutama kawasan dataran dan bagian hilir dari Daerah Aliran Sungai (DAS) di wilayah tersebut. Suku bangsa Banjar berasal dari daerah Banjar yaitu wilayah inti dari Kesultanan Banjar meliputi DAS Barito bagian hilir, DAS Bahan (Negara), DAS Martapura dan DAS 
di Indonesia telah mengalami suatu pergeseran kehidupan sosial. Sebagian adat yang berlaku mulai hilang seiring dengan kemajuan zaman. Banyaknya pendatang dan perkawinan campuran antar daerah lain yang berada di Banjarmasin merupakan salah satu sebab terjadinya perubahan sosial dan nilai-nilai adat dalam masyarakat. Meskipun, studi terhadap masyarakat adat Banjar masih merupakan studi yang penting untuk dikaji lebih jauh. Terkhusus pula tentang hubungannya dengan pengaruh Islam di daerah ini.

Banyaknya pondok pasantren di Kal-Sel merupakan bukti kuatnya akar dan pengaruh Islam di daerah ini. Tercatat ada 241 buah ponpes, 90 persen bersifat sudah modern (B.Post, kamis, 8 / 12), dan hampir kesemuanya adalah berlatar belakang NU. ${ }^{2}$ Pimpinan pondok pasantren di Kal-Sel punya sebutan KH (Kiyai Haji) seperti halnya pinpinan pondok pasantren di Jawa. Gerakan Ikatan Perkumpulan Pondok Pesantren Nahdatul Ulama adalah salah satu bukti kuat hubungan antar pasantren di Kal-Sel dan perwujudan pengakuan keteguhan gerakan NU.

Tabanio. Kesultanan Banjar sebelumnya meliputi wilayah provinsi Kalimantan Selatan dan Kalimantan Tengah, kemudian terpecah di sebelah barat menjadi kerajaan Kotawaringin yang dipimpin Pangeran Dipati Anta Kasuma dan di sebelah timur menjadi kerajaan Tanah Bumbu yang dipimpin Pangeran Dipati Tuha yang berkembang menjadi beberapa daerah : Sabamban, Pegatan, Koensan, Poelau Laoet, Batoe Litjin, Cangtoeng, Bangkalaan, Sampanahan, Manoenggoel, dan Tjingal. Wilayah Kalimantan Tengah dan Kalimantan Timur merupakan tanah rantau primer, selanjutnya dengan budaya madam, orang Banjar merantau hingga ke luar pulau. http:// id.wikipedia.org/wiki/Suku_Banjar.

${ }^{2}$ Ada beberapa buah pasantren ditemukan beraliran Muhammadiyah seperti al Furqon, dan Ibtidaiyah Diniyyah dan aliran mandiri (bukan NU dan Muhammadiyah).seperti pasantren ustadz Lutfi di Sei Mesa.
Kajian atas pergeseran gerakan dan perspektif masyarakat Banjar terhadap kiyai NU yang kini mulai tampak dirasakan di Kal-Sel sangat penting dikaji. Tentu saja akan terlihat prilaku keagamaan baru dalam bentukan kultural baru pula. Meskipun secara substansif ketaatan pada seorang tokoh agama (kiyai=tuan guru) tidak berubah namun perspektifnya mulai berubah seiring dengan kondisi dan perubahan sosial yang terjadi dewasa ini. Untuk itu tulisan ini berupaya mengamati perubahan atau pergeserakan pola gerakan keagamaan dalam konteks keumatan yang terjadi di kal-sel sebagai gerakan keagamaan yang tergerak sendiri karena datangnya nilai-nilai sosial baru.

\section{B. Kiyai NU dan Keumatan : Gerakan Keagamaan Sentris Menuju Objektivitas}

NU merupakan wadah keyakinan keberagamaan umumnya masyarakat Banjar. Meskipun sebagian kecil yang lain beraliran kemuhamadiyahan. Namun bisa dikatakan, mayoritas muslim di sini mengabadikan diri mereka dalam pengakuan dan fanatisme tinggi sebagai warga NU. Mereka lebih sering menyebut diri sebagai pengikut kaum Tuha. Istilah terakhir ini sebenarnya tidak ada hubungannya dengan gerakan padri di Sumatera. Namun di tahun 70-an sampai 80-an situasi pernah memanas terutama di daerah Hulu Sungai Utara di mana terjadi pengelompokan fanatisme kelompok yang cukup tajam antara kaum Tuha (tua) dan kaum Muda. Dan seterusnya berpengaruh keseluruh masyarakat Kal-Sel. Tidak diketahui, siapakah yang mula-mula menyebut istilah ini. Sebutan kaum Tuha adalah 
berbasis NU sedangkan kaum muda tidak lain adalah Muhamadiyah. Dan hampir saja, situasi memanas tersebut terjadi kekerasan antar kelompok (meskipun beberapa data ditemukan atas laporan dari orang-orang tua bahwa waktu itu sempat terjadi kekerasan antara mereka).

Namun, fanatisme terhadap NU bagi warga Nahdiyin suku Banjar kesemuanya didasarkan kepada ketaatan pada kiyai atau tuan guru (biasa bercirikan memakai sorban bolang putih). Sang kiyai ini biasanya adalah pimpinan Ponpes masing-masing daerah (banua) yang selalu mengindetitaskan diri sebagai orang NU. Paling tidak yang sangat berkesan terjadi antara tahun 70-an hingga 80an. Hingga kini kultur demikian masih tampak di mana fanatisme sebagai warga Nahdiyin tetap terpelihara. Meskipun telah mulai terjadi pergeseran perspektif tentang kiyai (tuan guru). Kiyai dianggap segalanya dalam kehidupan beragama, menentukan hukum-hukum dan amaliyah kehidupan warga. Dari soal kelahiran anak, pendidikan, rumah tangga, ekonomi keluarga dan usaha-bisnis, zakat, infaq, sadaqah hingga kematian, Kiyai sangat berperan dalam masyarakat di Kal-Sel. Kiyai atau tuan guru (Banjar) menjadi ego sentris dalam kehidupan beragama.

Kiyai NU sangat akrab dengan dengan ranah tradisi lokal. Pengislaman tradisi (budaya) lokal menjadi tradisi kultural NU merupakan fenomena sentris dari para kiyai NU di daerah ini. Terlebih dikarenakan masyarakat Banjar merupakan masyarakat yang memiliki sejarah kental atas budaya keratonkerajaan Banjar yang banyak memiliki aspek budaya tempatan yang lekat dengan kehidupan masyarakat. Dalam konteks budaya ada istilah budaya keraton;kerajaan dan budaya populer. Dua kebudayaan ini sering dikategorikan dengan kebudayaan tradisional (Kuntowijoyo;1993:230). Maka pada aspek ini kiyai dalam tradisi kultural masyarakat Banjar dijadikan bukan hanya sebagai pemuka agama tetapi juga sebagai pemimpin kemanyarakatan. Bahkan melebihi dari seorang pemuka adat. Keadaan ini lebih dikenal betapa pengaruh tradisi NU pada upacara sosial budaya populer. misalnya Tradisi adat batapung tawar tetap dilestarikan tetapi diiringi dengan doa-doa dipimpin oleh pemuka agama. Tradisi ini merupakan tradisi dalam rangka penyelamatan terhadap suatu keadaan yang dihajatkan misalnya membuka rumah baru, kendaraan, peresmian, ketika acara akikah anak dan perkawinan. Budaya lokal tentang bamandi-mandi (calon pengantin) dengan berbagai penyertaan doa-doa keagamaan. Selamatan hamil 7 bulan, menginjak telur. Selamatan hendak naik haji. Selamatan keliling kampung dengan mengarak kitab Shahih Bukhari sambil berdoa agar terhindar musibah (biasanya dari kebakaran).

Dalam konsep lain, tradisi NU juga masuk dari ritual-ritual pada budaya sehingga mengubahnya menjadi simbolik keIslaman tradisional misalnya acara haul kematian, pembacaan doa arwah setelah tiga hari kematian, kemudian 7 hari kematian, 25 hari kematian dan 100 hari kematian hingga haul (tahunan) merupakan tradisi lokal yang diislamkan dengan tradisi doadoa.

Demikian pula pola-pola mistik lokal diislamkan. Budaya ilmu-ilmu mistik telah dirombak dengan penyertaan doa 
seperti zimat kayu diganti dengan ayatul Qur'an, budaya mandi kekebalan dengan kembang, kue lakatan dengan mantra-mantra diganti dengan doa dan ayat al Qur'an. Tradisi lokal menggunakan minyak-minyak hasil lampah digunung diganti dengan rajah tubuh (tulisan arab). Bahkan ada tip keagamaan untuk membuang semua yang dianggap ilmu hitam (biasanya mampu dihilangkan oleh kiyai). Jadi kiyai dalam konteks ini selalu diyakini oleh masyarakat bukan hanya ahli agama tetapi juga ahli ilmu-ilmu gaib. NU yang mentradisi ditangan para kiyai sungguh sangat berhasil mengislamkan semua hal dalam tradisi lokal masyarakat Banjar. Semua hal yang berawal dengan mantra sudah berganti dengan kalimat seperti Bismillah, berkat Laa ilaaha illallah ataupun syahadatain. Bahkan dari sekitar bacaan itu berkembang menjadi sumber-sumber keilmuan gaib dan aneh di masyarakat misalnya kalimah berampun diambil dari kalimat Laa Ilaaha Illallah.

Tradisi NU di sini juga masuk dalam dunia seni. Perayaan maulid, untuk selamatan rumah maupun acara lainnya biasanya dibawakan syair-syair maulid al Habsyi. Di era 90-an maulid al Habsyi menjadi trend anak santri dan masyarakat kebanyakan. Padahal sebelum syair ini, seperti ad Diba'i lebih dulu dikenal namun tidak sempat menjadi kegemaran anak-anak santri di pasantren maupun di masyarakat. Syair al Habsyi disertai dengan terbangan (alat tabur dari kulit sapi) menjadi acara dominan terjadi dalam tradisi NU. Tradisi ini jelas di bawa tokoh keagamaan NU dari luar. Namun pengawinan dengan seni lokal juga kerab terjadi seperti seni Hadrah. Seni ini merupakan kombinasi seni tari dan seni perang serta seni arak raja. Uniknya meskipun menggunakan gendang besar namun lagu yang dikumandangkan adalah syair-syair yang ada dalam Diba maupun al Habsyi maupun salawat ciptaan pemuka agama dulu.

Dengan tradisi kultural NU maka pendapat-pendapat keagamaan yang bersifat baru dan terlihat berbeda atau berlawanan dengan tradisi dan fatwa kiyai akan ditepis dengan mudah. Isu gender, persamaan hak kaum perempuan dan lelaki, HAM, tidak berpengaruh dalam keumatan masyarakat Banjar yang lebih tertarik dengan nasehat kiyai sebagai tuan guru. Hingga sekarang kiyai menjadi panutan yang dominan dan keadaan ini merupakan tradisi NU di Kal-Sel, meskipun ada perbedaan dengan era tahun 70-an-hingga 80-an. Sebut saja bila seorang pejabat ingin disukai oleh masyarakat maka cukup ia mendekati seorang kiyai yang banyak umatnya maka iapun akan dicintai. keadaan tersebut membawa kiyai mulai mengarahkan pada haluan politiknya. Kebetulan NU pusat sendiri mengibarkan haluan politiknya. Masa-masa ini warga Nahdiyin di Kal-Sel tetap memiliki semangat mengikuti kehendak kiyai. Termasuk dalam haluan politik. Sebut saja jika seorang kiyai menunjuk suatu partai (tahun 80-an hingga 90-an) di mana kebanyakan kiyai NU Kal-Sel mulai mengarahkan haluan politiknya pada P3 yang berlambang ka'bah maka hampir semua warga nahdiyin Kal-Sel memilih P3. ini membuktikan bahwa kiyai dan kehidupan pasantren pada waktu itu benar-benar sangat berpengaruh dalam kehidupan masyarakat Banjar. 
Kini, kondisi tersebut tidak lagi terjadi, atau sejak tahun 90-an. Mulai terjadi tarik menarik cara pandang yang berbeda. sebut saja ada seorang kiyai ikut pada suatu partai yang bukan P3 maka umat pengajiannya drastis berkurang hingga $75 \%$ seperti yang pernah terjadi di kota Banjarmasin dan Martapura hingga menjadi trend di semua benua daerah Kal-Sel. Para kiyai sendiri ternyata mulai menyadari keadaan tersebut. Pengaruh globalisasi dan siaran TV sudah mulai masuk kesegenap penjuru Kal-Sel. Terlebih ketika masuknya TV swasta di Kal-Sel. Masyarakat mulai bersinggungan secara global pada dunia luar. Isu-isu demokrasi, keterbukaan, kebebasan berpendapat yang digiring televisi memiliki dampak besar di daerah ini. Perubahan drastis terjadi bahkan menjadi baikot masa terhadap seorang kiyai yang mengikuti politik praktis. Sang tuan guru; kiyai dianggap harus tidak memiliki kepentingan politik terhadap partai manapun. Dengan kata lain, corak dominan pergeseran perspektif masyarakat keagamaan mulai tampak terlihat jelas ditandai dengan tidak inginnya kebanyakan warga melihat kiyai mereka terjun ke politik praktis. Mereka sekarang ini juga mulai membicarakan tingkah laku seorang kiyai (tuan guru) jika berbuat sesuatu yang tabu (misalnya soal poligami kiyai) maupun atas pendapat kiyai tentang suatu hukum, perkembangan politik maupun kepengurusan Mesjid-Mesjid besar yang berhubungan dengan Pemerintah Daerah. Semua ini dulu di tahun 70-an hingga 80-an merupakan soal yang tabu diungkapkan antar warga. Keadaan ini disadari oleh banyak kiayi; tuan guru NU. Tahun 90-an seorang tuan guru besar (kiyai) ${ }^{3}$ dengan murid berjumlah puluhan ribu orang dalam pengajiannya mengatakan bahwa ia tak mengikuti partai politik apapun. Kiyai seperti ini menjadi panutan besar bagi warga NU masyarakat Banjar, sebab lebih dianggap santun dan sesuai dengan kehendak umat.

Dengan demikian, meskipun tuan guru; kiyai NU masih dominan ditaati sebagaimana pada tahun 70-an hingga 80-an dalam segala hal urusan keagamaan bahkan di luar dari pada itu, maka sejak tahun 90-an hingga sekarang pola ketaatan mulai berubah. Terjadi pergeseran kepercayaan menenpatkan tokoh agama; kiyai sebagai ulama. Dalam hal politik, warga NU sekarang menganggap bukan bidang kiyai. Tugas seorang kiyai adalah semata keagamaan, pembimbing umat. Kenyataan ini hingga sekarang masih tampak terlihat. Misalnya sejak tahun 1999 hingga 2009 sekarang, suara PKB di daerah ini tidak besar (walaupun PKB sempat meraih No.2 setelah Jatim) tetapi jauh dari seharusnya terlebih di daerah ini ada banyak tokoh agama; kiyai NU ikut di dalamnya, tidaklah diikuti oleh warga nahdiyin di Kal-Sel. Mereka memilih sendiri haluan politik praktis mereka. Jadi NU murni dipahami masyarakat Banjar sebagai organisasi sosial keagamaan bukan politis. Artinya upaya untuk menciptakan NU secara de jure memainkan sebagai organisasi

${ }^{3}$ Almarhum al alamah KH. Zaini Ghanie, sering pula disebut dengan Tuan Guru Besar, syekh sakumpul hingga sekarang makam beliau terus diziarahi dari berbagai daerah. Beliau termasuk keturunan ketujuh dari Syekh M. Arsyad al Banjari (pengarang kitab Sabilal Muhtadin), seperguruan dengan tokoh syekh Palimbani Sumatera ketika belajar di Mekkah. Sewaktu beliau hidup dikunjungi oleh beberapa president RI dan para mentri. 
sosial keagamaan, dan secara de facto NU bermain politik praktis lewat PKB, sebagai partai yang mendapat fasilitas dan dilahirkan oleh NU tidak adaptif dalam masyarakat Banjar meskipun diterima oleh sebagian kecil warga masyarakat Nahdiyin di daerah ini.

Isu gender tidak begitu berpengaruh hingga sekarang di daerah ini. Dominasi pola fanatisme pada tokoh agama sangat kuat. Tokoh agama setempat jika ditanya tentang masalah ini terlihat tidak setuju. Demikian pula soal penentangan pada poligami. Ini membuktikan bahwa di daerah ini masih menunjukkan pola kultural terjadi dominan di masyarakat, meskipun kaum perempuannya kebanyakan menolak di poligami namun secara diam-diam diakui sebagai ajaran agama. Hal ini tidak lepas dari pendapat yang berkembang di kalangan para tokoh agama; kiyai. Beberapa kasus seorang kiyai yang berpoligami sempat menjadi pembicaraan secara sembunyisembunyi namun tak sempat menjadi isu negatif terhadap keadaan sang kiyai. Ketaatan pada sang kiyai lebih fundamen ketimbang masalah poligami.

\section{Munculnya Santri Modern ; Pergumulan Pemikiran Tokoh Keagamaan}

Masuk dan berdirinya IAIN Antasari di Kal-Sel pada tahun 70-an sebenarnya cukup dominan berpengaruh pada para lulusan di Perguruan Tinggi agama Islam ini. Tidak hanya warga umum yang memasukkan anak mereka ke Perguruan agama Islam, tetapi juga anak-anak kiyai NU sendiri. Setelah mereka menamatkan kesantrian mereka di pondok pasantren, biasanya para lulusannya digiring untuk masuk IAIN.
Maklum pula, pengajarnya sendiri di era tahun 70-an adalah kebanyakan kaum Tuha (tua) yang memiliki basis masa di masyarakat dan sebagian lainnya merupakan alumni Cairo dan IAIN di tanah Jawa. Alhasil IAIN di tahuntahun berikutnya menjadi sentral kajian keagamaan modern di Kal-Sel.. Maka di atas tahun 80-an sudah mulai banyak kelulusan IAIN. Bisa dikatakan lulusan ini ketika menjadi tokoh agama sebenarnya lebih layak disebut sebagai kiyai atau ulama modern. Sebutan ulama sebenarnya sangat luas dan komplek. Namun pada dasarnya mereka adalah pendidik. Mulai menjalankan peranannya sebagai pendidik, seorang ulama bisa berkembang menjadi pemimpin masyarakat, tokoh politik atau ilmuwan (Dawam Rahardjo;1993). Sebutan kiyai, tuan guru adalah menunjuk pada kemampuan pendidikan keagamaan bagi umat dan dalam konteks inilah maksud kita dalam tulisan ini.

Sebagian mereka ada yang menjadi tokoh tempatan, terutama yang telah lama nyantri di pasantren lalu meneruskannya ke IAIN. Haluan berpikir mereka kembali pada pola tradionalistik NU, sebagian seperti orang tua mereka yang juga kiyai. Sebagian lulusan IAIN yang lain menjadi PNS dan bekerja di Depag setempat. Sebagian lagi menjadi tokoh agama setempat. Bagian yang menarik dari mereka adalah ketika mereka menyuarakan pemikiran keagamaan berbeda pendapat dengan tradisi kiyai. Disadari atau tidak mulai terjadi pergumulan pemikiran baru terhadap agama. Meskipun kelompok ini jumlahnya sangatlah sedikit namun mereka didukung oleh sedikit lulusan Cairo, terkadang sebagian orang Muham- 
madiyah. Pergumulan pemikiran tersebut keadaannya hingga kini terus berlanjut. Tokoh agama yang lulusan IAIN biasanya tidak menggunakan ciri khas sorban bolang putih. Mereka lebih suka memaki peci nasional sedang sorban hanya digantungkan di leher. Berbeda dengan tradisi lama sebagai tokoh agama adalah memakai sorbanbolang di kepala ketika mereka terjun ke Masyarakat (ceramah agama, khutbah maupun acara keagamaan lainnya). Di samping itu ada gelar seperti Drs, S.Ag, sebagai ciri khas mereka. Keberpihakan agar warga masyarakat; suku Banjar untuk tidak taklid pada seseorang atau terhadap madzhab hukum agama adalah elan dasar dari gerakan pemikiran ini. Meskipun mereka tidak mengelompok dalam satu wadah gerakan namun pola pemikiran mereka ada kemiripan yang sama antar mereka dalam mempengaruhi masyarakat setempat. Hanya keberadaan mereka lebih banyak di kota besar Banjarmasin. Sangat minim di daerah banua lima. Di bawah ini dapat digenalisir pemikiran mereka yang mencirikan dan pola pembaruan dalam masyarakat Nahdiyin Kal-Sel, sbb:

1. Tidak harus bertaklid pada satu madzhab tertentu;

2. Menutamakan bahan ceramah al Qur'an dan Hadis ketimbang kitabkitab kuning;

3. Menanggapi atas isu keagamaan yang terjadi di masyarakat;

4. Memberikan syarat yang ketat pada Poligami;

5. Cendrung menolak tasawuf falsafi;

6. Meniadakan Tawasul pada wali-wali dalam berdoa.

7. Meninggalkan tradisi pembacaan manakib syekh Abdul Kadir Jailani dan syekh Seman.
8. Kurang akomadatif dengan kultur lokal / adat yang selama ini dipelihara oleh kaum Tua;

9. Meninggalkan syair-syair spritual yang ada dalam masyarakat;

10. Menolak segala bentuk pemahaman keagamaan liberalisme dan sekuler.

11. Pengembangan ketaatan beragama yang lebih baik sebagai penyeimbang dengan urusan duniawi yang tidak boleh ditinggalkan.

Pola pemikiran di atas jauh berbeda dengan konteks kelompok muda NU ataupun kaum muda NU Profresif yang akhir-akhir ini mengemuka dalam tulisan Lauda Ida (NU Muda; Kaum Progresif Dan Sekularisme Baru) Sebab ciri mereka justru menolak paham keagamaan yang liberal maupun pengarahan pada paham sekuler. Meskipun gerakan pemikiran keagamaan tersebut tidak mengelompok pada suatu tempat dan jadual tertentu, ataupun dipimpin oleh seseorng namun mereka sepakat menolak segala liberalisme keagamaan, misalnya terhadap pemikiran liberalisme (Hartono Ahmad Jaiz, 2005: 109-110 dalam Atho' Mudzhar):

1. Al-Quran adalah teks dan harus dikaji dengan hermeneutika

2. Kitab-kitab tafsir klasik itu tidak diperlukan lagi

3. Poligami harus dilarang

4. Mahar dalam perkawinan boleh dibayar oleh suami atau isteri.

5. Masa iddah juga harus dikenakan kepada laki-laki, baik cerai hidup ataupun cerai mati

6. Pernikahan untuk jangka waktu tertentu boleh hukumnya

7. Perkawinan dengan orang yang berbeda agama dibolehkan kepada laki-laki atau perempuan muslim

8. Bagian warisan untuk anak laki-laki dan anak perempuan sama 1:1 
9. Anak di luar nikah yang diketahui secara pasti ayah biologisnya tetap mendapatkan hak warisan dari ayahnya.

Tokoh-tokoh keagamaan alumni IAIN tersebut sebenarnya lebih bercorak pada intelektual keagamaan dan kebanyakan mereka bersifat indefendent, tidak mengkulturkan fanatisme pada Nahdatul Ulama ataupun berpihak pada tradisi kultural NU sekalipun terkadang orang tua mereka justru tokoh NU. Pola penerimaan masyarakat Kal-Sel terhadap mereka dikarenakan beberapa sebab, sbb :

1. Agresif untuk dipanggil mengisi acara keagamaan seperti ceramah pada hari-hari besar Islam, acara non resmi perusahan-instansi; selamatan berisi ceramah agama, aqiqah, selamatan haji.

2. Komunikatif, dianggap lebih mengerti dengan perasaan masyarakat dan sering dapat menghibur dengan bahasa yang kocak.

3. Akomodatif, tanpa ada birokrasi bahkan bisa hanya melewati telpon dalam hal memanggil untuk mengisi acara keagamaan.

4. Berani menyinggung kesalahan pejabat; pemerintah maupun pengusaha.

5. Mudah didekati oleh setiap orang dan cepat akrab.

6. Mudah dinalar dan dipahami oleh semua kalangan dari masyarakat awam maupun yang terdidik.

7. Adanya perubahan sosial global yang mempengaruh cara berpikir kebanyakan orang termasuk masyarakat kal-sel ke arah rasionalisme.

Keberadaan mereka sering pula mengusik tokoh keagamaan senior di Kal-Sel sehingga di antara mereka ada yang menyinggung dalam ceramahnya untuk tidak mendengarkan ataupun mengikuti orang-orang yang memiliki gelar kesarjanaan (Drs, S.Ag). isu negatif terhadap kelompok ini tidak direspon balik terhadapnya mengakibatkan hubungan yang kurang harmonis antar mereka tanpa ada counter. Bahkan IAIN sendiri dikritik yang sekarang lebih banyak menelurkan orang-orang yang tidak dapat merapat dengan tradisionalisme NU.

Meskipun demikian masyarakat KalSel menyikapinya dengan beragam pendapat namun dalam banyak kesempatan mereka tetap diterima. Hal ini juga didukung oleh faktor banyaknya pertemuan keagamaan yang harus di isi oleh nara sumber/tokoh keagamaan, sementara tokoh keagamaan senior atau kaum Tua jumlahnya sedikit dan padat waktu, birokratif dan sering dikeluhkan ongkos biaya yang mahal. Santri modern ataupun istilah kiyai modern atau ustadz modern, selalu tidak menyentuhkan diri mereka pada politik praktis ataupun atas suatu kepentingan politik yang berkembang di daerah mereka. Barangkali rasa kebertakutan terhadap dan mungkin akan dijauhi oleh umat adalah alasan utama kelompok ini. Sebab di Kal-Sel kasus seperti demikian telah beberapa kali terjadi dan sempat menjadi isu yang mengemuka untuk sekian waktu. Peristiwa itu menjadi pelajaran bagi pelaku dakwah di wilayah ini.

\section{D.Kaum Muda Islam ; Keberpihakan Pada Islam Non Kultural}

Selama masa pesat berkembangnya NU di Kal-Sel, sebelum dan sesudah tahun 70-an hingga 90-an, bisa dikatakan keIslaman seseorang di 
daerah ini didasarkan pada aspek kultural kaum nahdiyin yang berperan memberikan nilai positip dalam dakwah Islamiyah. Dengan kata lain, hampir sulit membedakan antara istilah Islam dan NU. Seperti halnya masyarakat kultural Madura dan Jatim. Maksudnya, Islam dan NU tidak dapat dipisahkan dari pikiran orang yang beragama (Islam). Hampir di seluruh banua lima, tokoh sentral keagamaan selalu orang NU. Tokoh NU sangat disegani (hingga sekarang sebagian hal ini masih tampak pada tokoh NU). Tokoh NU pastilah ulama dan kebanyakan mereka adalah pimpinan pondok pasantren atau hidup dalam dunia pasantren dan masyarakat luas. Mereka besar diakar rumput seperti halnya NU dalam masyarakat suku Banjar. Di sini terlihat betapa besar dan berpengaruhnya NU dalam masyarakat sebagai organisasi yang bergerak dengan semangat harakatul diniyah (gerakan keagamaan), harakatul adabiyah (gerakan moral) maupun sebagai organisasi besar; harakatul ijtimaiyyah (gerakan keorganisasian), dengan paham ahlus sunnah wal jamaah.

Untuk menjadi orang besar dan disegani serta diikuti oleh masyarakat muslim maka orang tersebut haruslah beraliran NU. Saat itu sulit orang yang berhaluan di luar NU untuk dapat menjadi kiyai di masyarakat. Hingga sekarangnya kenyataan tersebut masih dirasakan. Dengan kata lain saat itu, setiap ulama pastilah NU dan untuk mencari Islam yang kuat pastilah NU. Realitas ini bukan berarti menapikan gerakan Muhammadiyah yang juga berkembang di Kal-Sel serta urbanisasi masyarakat luar di Kal-Sel. Namun bahasan ini menunjuk pada strategi ril pada dimensi waktu dan keadaan tertentu. NU hampir dikata seperti agama atau identik dengan Islam. Perlawanan terhadapnya akan memungkinkan terjadi kekerasan antar kelompok. Sebagai ilustrasi, di tahun 90an seorang ustadz yang sedikit berbeda dengan pendapat masyarakat; ketika di jalan menemui kecelakaan. Kendaraan beliau bertabrakan dengan kendaraan lain yang juga ditumpangi oleh seseorang. Kaca mata beliau pecah. Tetapi orang tersebut tidak merasa kasihan dengan beliau. Alasannya karena beliau bukan berhaluan NU.

Selama zaman kerajaan Banjar Islam, tokoh Panutan masyarakat KalSel adalah Syekh besar Muhammad Arsyad al Banjari (pengarang kitab Sabilal Muhtadin). Selama ratusan tahun keturunan beliau menjadi agent sentral kekuatan dakwah di masyarakat Banjar. Hingga sekarang, keturunannya menjadi tokoh keagamaan yang dihormati. Dan kebetulan, tokoh keagamaan keturunan beliau adalah orang-orang NU. Meskipun tidak harus menjadi pengurus NU di daerah namun mereka menjadi tokoh sentral NU. Pendapat mereka menjadi nasehat jajaran pengurus NU di semua daerah. Martapura adalah daerah hidup keturunan syekh besar hingga sekarang. Kota ini disebut sebagai kota serambi Mekkah karena bertaburnya ulama. Daerah ini sangat berpengaruh. Hidup dari masa ke masa ulama besar Kal-Sel di sini. Pasantren Darus Salam adalah salah satu aset kader keulamaan di tempat ini. Di antara mereka tokoh yang berpengaruh adalah $\mathrm{KH}$. Badaruddin (w.1992) dan KH. Zaini Mugni (w.2005), guru dan murid ini secara luar biasa memiliki murid berjumlah puluhan ribu banyaknya.

Pengaruh globalisasi modern terhadap dunia ketiga khususnya 
Indonesia dan tak terhindarkan pula masyarakat muslim kal-sel telah mengubah sosial kultur masyarakat. Kehidupan modern mulai menggoyang dan mengikis ciri-ciri hidup "paguyuban". Cara hidup dan kerja masyarakat dalam mengejar ekonomi telah berbeda dan semakin terus berubah. Tuntutan hidup mulai dirasakan ke seluruh daerah. Saat itu menurut Dawam Rahardjo adalah hambarnya nilai-nilai transendental. Seperti halnya masyarakat di semua daerah di Indonesia, masyarakat kal-sel juga merasakan pengaruh modernisasi. Misalnya upaya penyesuaian diri dan adaptasi terhadap proses modernisas. Sebagian melakukan apologi terhadap ajaran Islam dan menolak modernisasi yang bernilai westernisasi. Sebagian menolak secara formal namun mereka menerima nilai-nilai itu seperti praktek kapitalisme atau konsumerisme. (Dawam; 1993:382). Setiap anak mulai dituntut untuk sekolah setinggi mungkin dengan tujuan untuk mendapatkan pekerjaan. Hampir dalam semua hal, haluan pikiran orang tertumpu pada aspek ekonomi. Globalisasi juga menggelindingkan sekularisme penciptaan dengan anaknya yang bernama liberalisme dan kapitalisme. Liberalisme adalah ajaran yang sesat yang harus ditentang. Liberalisme mengakibatkan individualisme dan individualisme mengakibatkan kapitalisme. Maka dalam kapitalisme ini, prinsip kemerdekaan dinodai sedemikian rupa (Nurkholis Madjid; 1994:188).

Tradisi kultural NU di daerah ini meskipun cukup kuat untuk mereduksi perubahan sosial-ekonomi masyarakat, kerapkali pula gagal melawan arus deras modernisasi yang memberi dampak pada sifat individualisme ekonomi, sosial dan politik. Sebagai contoh adalah banyaknya sekolah-sekolah umum negeri yang di buka oleh pemerintah di wilayah kal-sel sampai ke pelosok pedesaan-kampung-kampung justru diminati oleh masyarakat suku Banjar. Padahal pasantren di wilayah ini begitu banyak yaitu mencapai lebih dari 241 buah (B.Post, kamis,8/12). Anak negeri ini mulai menyekolahkan anak mereka di lembaga-lembaga negeri dengan tujuan pencapaian pekerjaan yang layak seiring dengan realitas pekerjaan modern memerlukan ijazah formil. Meskipun data langsung di lapangan jumlah murid di pasantren tidak berkurang namun penambahan jumlah pasantren mulai berkurang dibanding era 70-an hingga 80-an. Cara pandang dan perubahan atas ekonomi masyarakat telah membawa perubahan sosial kultural baru.

Tradisi kultural NU dalam masyarakat Banjar seperti kemampuan dan kepandaian anak membaca kitab kuning sekarang mulai dirasakan langka. Bahkan kemampuan bisa membaca al Qur'an yang dulu dipastikan ciri khas masyarakat Banjar mulai sulit dipertahankan. Tahun 70-an, seorang pria yang ingin melamar seorang perempuan harus menamatkan dulu al Qur'an (khatam al Qur'an). Demikian pula bagi kaum perempuannya sebelum mereka melangsungkan pernikahan. Keadaan ini mulai ditinggalkan dikarenakan kemampuan tersebut tidak mereka dapatkan di bangku sekolah negeri pemerintah. Tradisi khatam al Qur'an pada masyarakat suku Banjar pada umur 7 sampai dengan 10 tahun juga sulit ditemukan yang dulu setiap kampung melakukan acara masal 
khataman al Qur'an. Meskiipun tradisi membaca wirid selesai salat Magrib dan subuh secara bersama-sama di mesjid masih terdengar dan terpelihara namun yang mengisi acara tersebut pada umumnya adalah orang-orang tua, bukan anak muda. Terkecuali daerah tertentu seperti Martapura.

Keadaan demikian dirasakan oleh pemuka dan tokoh keagamaan Kal-Sel, baik dalam kalangan senior NU maupun para Da'i dari berbagai kalangan; lulusan IAIN maupun organisasi Islam yang ada di Kal-Sel. Tahun 2000 merupakan tahun kritik bagi Kaum muda Islam dan mereka selalu menjadi objek sorotan. Tahuntahun ini kegairahan anak muda Islam mulai terlihat pada kegiatan keagamaan. Di Kampus-kampus mulai tumbuh pengajian. Demikian pula kesadaran para guru sekolah negeri untuk memasukkan pelajaran agama sebagai pelajaran lokal mulai dilakukan. Anakanak muda Islam mulai gemar membaca al Qur'an. Pada bulan ramadhan, aktivitas anak SD hingga SMA memadati mesjid dalam kegiatan tadarus dan ceramah keagamaan yang diisi oleh ustadz-ustadz muda, terutama lulusan IAIN (terutama diperkotaanBanjarmasin). Demikian pula di Perguruan Tinggi Umum. Jilbab mulai tidak asing lagi bagi anak muslimah. Bahkan di Perguruan Tinggi seperti kedokteran, keperawatan dan kebidanan, jilbab sempat menjadi trend. Islam dipelajari dari berbagai kalangan anak muda Islam. Ini tidak lepas dari dukungan orang tua di kal-sel yang sekarang merasakan adanya perubahan kultural yang makin menjauh dari nilai keagamaan.

Islam dipelajari oleh kaum muda Islam; anak-anak terpelajar adalah Islam universal. Pembelajaran yang sifatnya terserak-serak oleh para da'i muda (ustadz-kiyai modern) lebih cendrung pada percepatan pemahaman dan prioritas. Berbeda dengan anak yang nyantri di pasantren. Mereka belajar Islam dari yang paling dasar hingga Islam dalam ranah lokal dan tradisi NU. Bagi kalangan santri, keahlian bahasa arab; kitab kuning merupakan dasar utama dalam mempelajari Islam. Kajian agama diarahkan pada sifatnya yang tartil, bertahap dan mendalam. Studi fiqh diajarkan bukan hanya pada matannya (isi) tetapi juga pada syarahnya (penjelasan-tafsili). Ilmu tauhid melebar hingga ilmu kalam. Hal ini terbukti dengan kitab-kitab tauhid di pasantren umumnya mengandung filsafat yang lebih cendrung pada ilmu kalam. Sehingga pembahasan dirasakan sangat mendalam. Bukan hanya mengetahui dalil naqli tetapi juga dalil rasio (aqli). Kajian keagamaan (Islam) dalam dunia santri harus menguak perbagai makna eksoteris maupun esoteris. Bahkan, studi terhadap syairsyair arab ataupun kajian sastra selalu dipolakan dalam pasantren. Bahkan tradisi NU dan ranah lokal dihidupkan dalam dunia santri. Harapan semua kiyai di pasantren adalah mencetak kader kiyai NU dan menjadi pemuka dan tokoh keagamaan di masyarakat.

Berbeda dengan dunia santri, anak muda Islam yang sekarang belajar Islam dari pola pemahaman cepat dan prioritas mengakibatkan kaum muda Islam memahami Islam secara eksoteris dan tidak mengetahui Islam kultural dalam hal ini adalah ranah lokal dan tradisi kultural NU. Mereka juga asing dengan bahasa arab terlebih sastra arab. Fiqh hanya mereka ketahui dalam skala tertentu, tidak mendalam. Demikian 
pula ilmu tauhid. Meskipun semangat mereka sangat dominan bahkan dapat menjelaskan keislaman. Jadi kondisi ini memungkinkan bahwa Islam dikenal dan terus menjadi tradisi pada masyarakat Banjar dengan kenyataan semangat anak-anak muda Islam untuk belajar Islam sangat tinggi dan antusias. Meskipun bagian yang esoteris dan tradisi kultural NU akan ditinggalkan sekurangnya dalam ranah lokal amaliyah masyarakat Banjar. Jadi Islam akan terlihat dalam corak baru pada tahun-tahun sekarang dan tahun berikutnya. Sekarang ini sudah terlihat kegiatan anak SD untuk belajar membaca al Qur'an. Metode yang digunakan tidak lagi metode tradisional tetapi metode modern (metode iqro) disemua pelosok daerah kal-sel. Tiap tahun ada ribuan anak yang tamat al Qur'an. Sebuah fenomena baru yang sangat menarik dan akan ditingkatkan lagi. Setidaknya sudah terlihat kader muslim yang menggambarkan begitu cerahnya Islam di bumi kal-sel untuk masa-masa akan datang. Meskipun pada konteks lain, kegairahan Islam bagi anak-anak umur SMP dan SMA lebih banyak terlihat pada bulan Ramadhan namun setidaknya anak-anak tersebut sudah mengenal Islam yang mungkin mereka tidak akan temukan di rumah mereka. Tetapi, mereka hanya mengenal Islam dalam lapisan percepatan dan prioritas.

Berangkat dari kenyataan demikian, kondisi ekonomi dan perubahan sosial dalam ring kehidupan modern telah memaksa nilai kultural NU mulai terkikis terutama pada kota besar Banjarmasin. Penyelamatan terhadapnya dilakukan oleh semua lapisan tokoh keagamaan di Kal-Sel dengan metode percepatan dan prioritas. Maka dalam konteks demikian, tanpa disadari terjadi suatu pergerakan pemahaman keagamaan bagi kaum muda Islam di Kal-Sel pada pola Islam Non Kultural. Degan kata lain terkader oleh keadaan baru dalam realitas kehidupan beragama pada pola Islam Non Kultural. Keadaan ini bukan berarti negatif. Namun bagi pihak kaum Nahdiyin adalah merugikan dalam aspek kedekatan pada tradisi NU namun menggembirakan bagi kelompok yang ingin melihat Islam dalam pemahaman yang murni tanpa serapan ranah lokal ataupun dalam konteks semata tradisi NU. Hanya santri di Pasanten yang akan kuat memegang dominasi tradisi NU dan masyarakat pedesaan.

\section{E. Penutup}

Berangkat dari uraian terdahulu, maka tradisi kultur NU yang terlekat pada masyarakat Banjar pada mulanya terjadi pada masyarakat pasantren. Kiyai-kiyai NU memulai dakwah mereka melewati dibukanya pondokpondok pasantren di sekitar kehidupan masyarakat. Pengaruh pasantren sangat luar biasa dalam pengembangan keagamaan. Baik dari segi keilmuan, pemikiran, sosial dan budaya. Berbeda dengan di tempat lain seperti di jawa ada istilah budaya Islam santri dan abangan (lih. Kuntowijoyo:237), maka dalam masyarakat Banjar tidak dikenal istilah demikian. Dalam kenyataannya sejak Islam masuk dalam kerajaan Islam Banjar (kesultanan Banjar), tradisi Islam mulai diberlakukan. Titah raja yang muslim menjadi kekuatan dasyat bagi rakyat untuk ditaati. Perlawanan terhadap Belanda dalam gerakan rakyat tidak lepas dari ruh Islam di tempat ini. Keadaan ini berlanjut seterusnya di mana ketika kerajaan Banjar tidak ada 
lagi dan diganti oleh masa kekuasaan Belanda, maka tampuk kekuatan Islam diemban oleh para kiyai; tuan guru di berbagai tempat hingga Belanda tidak lagi ada di wilayah Kalimantan Selatan.

Jalur laut yang dekat dengan Jawa selalu dimanfaatkan oleh masyarakat Banjar dalam komunikasi. Setidaknya Islam mulai ada pada kerajaan Banjar karena adanya hubungan dengan kerajaan Demak. Ketika itu Pangeran Samudera (Raja I) di Kerajaan Banjar. Setelah mendapat dukungan Kesultanan Demak untuk lepas dari Kerajaan Negara Daha (1526-1550) dipimpin khatib Dayan. Kemenangan kerajaan Islam mengharuskan raja Banjar masuk Islam. Mulailah pengaruh Islam masuk di wilayah ini dengan warna Islam Demak. Selanjutnya hubungan dekat itu terus terjalin. Banyaknya anak kiyai dan warga masyarakat menyokalahkan anak mereka ke Jatim membawa budaya tersendiri di belakang hari di wilayah ini (pada masa Kerajaan Banjar telah dimulai mengirim pelajar ke Mekkah namun jumlah mereka sangat sedikit). Ketika organisasi Islam Nahdatul Ulama berdiri, organisasi ini disambut baik oleh pemuka agama di wilayah ini. Di samping pemuka agama; kiyai-kiyai di sini adalah orang Banjar yang dulunya menuntut ilmu di tanah jawa, khususnya Jawa Timur, maka tempat Jatim juga merupakan tempat yang paling dekat dengan Kalimantan Selatan. Sementara Jawa Timur merupakan basis NU militan. Maka wajar daerah Kal-Sel menjadi basis kedua setelah Jatim. Sementara tradisi lama (masa kerajaan Banjar) menyekolahkan anak ke Mekkah tidak dapat diteruskan karena biaya yang mahal.
NU dengan sendirinya berkembang dalam masyarakat Banjar di dukung oleh para tokoh keagamaan. Terlebih ia didukung oleh keturunan orang yang paling berpengaruh tokoh keagamaan di kerajaan Banjar yaitu Syekh Besar Muhammad Arsyad al Banjari. Maka NU menjadi hidup dan adaptif dalam masyarakat Banjar. Bahkan NU menjadi instrument mentransformasikan Islam dalam budaya masyarakat lokal. Pengaruh NU dan Islam yang hampir sulit dipisahkan dalam kenyataan budaya - kultur masyarakat Banjar.

Mulai berdirinya sekolah-sekolah negeri di wilayah ini, terutama sejak tahun 80-an ke atas, mulai terjadi persangingan ketat dengan pasantren. Perubahan sosial-ekonomi mengharuskan banyak orang tua menyekolahkan anak mereka ke sekolah-sekolah negeri. Akibatnya beberapa tradisi kultur NU mulai tergoyang dan terkikis dalam masyarakat. Upaya penyeimbang dengan dakwah di luar pasantren mengakibatkan transformasi ilmu bersifat percepatan dan prioritas. Hal ini di dukung pula oleh da'i-da'i lulusan IAIN (sebagiannya) lebih berpihak pada Islam non kultural maka tradisi kultural NU mulai dirasakan terkikis terutama di kota besar Banjarmasin, meskipun untuk tahun-tahun akan datang, tradisi kultural tersebut tidak mungkin habis selama pasantren masih ada di tempat ini. Demikian juga, yang paling kontras terlihat pada bagian politik. Kiyai di sini tak dapat lagi mendoktrin haluan politiknya untuk menunjuk suatu partai menjadi harus diikuti. Fenomena ini dibuktikan dengan kalahnya PKB dan PKNU suaranya di Kal-Sel. Berbeda pada tahun-tahun 70an, di mana sifat ketaatan pada kiyai bersifat total. Dibuktikan dengan 
kemenangan P3 yang biasanya langsung dipimpin oleh para pemuka agama. Mungkin pula ada benarnya anggapan bahwa pergeseran tersebut karena pergeseran yang terjadi pada institusi NU sendiri dari politik kebangsaan menjadi politik kekuasaan.

Kondisi sekarang bisa dikatakan sebagai kondisi tarik menarik antara Islam kultur NU dengan Islam yang kurang berpihak pada kultur NU maupun budaya Lokal. Gerakan Muhammadiyah sangat mungkin menjadi lebih leluasa untuk menanamkan pemahamannya pada masyarakat. Terlebih, anak muda Islam di sini cukup antusias terhadap da'i-da'i muda lulusan IAIN (baik yang berpihak pada kultur NU maupun non tradisi NU). Maka akan sangat terlihat dan tampak pada masa-masa akan datang perubahan tersebut. Masuknya Hizbuz Tahrir di kampus-kampus untuk mengajarkan Islam juga merupakan fenomena baru. Meskipun pengaruhnya masih sangat kecil. Berbeda dengan yang pertama, totalitas ketaatan pada kiyai berkurang seiring dengan berkurangnya antusiasnya masyarakat pada NU itu sendiri karena dasyatnya perubahan sosial ekonomi. Di bawah ini ada beberapa point yang penting sebagai simpulan terjadinya pergeseran perspektif masyarakat Banjar terhadap kiyai NU maupun kenyataan rill NU sekarang sebagai gerakan keagamaan, sbb :

1. Kiyai ditaati selama tidak pada masalah politik (berbeda dengan era tahun 70-an hingga 80-an ke atas).

2. Isu-isu gender tidak diterima oleh masyarakat Banjar karena tidak mendapat dukungan dari para kiyai NU.

3. Beberapa tradisi kultur NU tidak lagi diamalkan oleh umum masyarakat terutama masyarakat perkotaan (Banjarmasin) karena pengaruh sosial ekonomi maupun adanya dakwah lain yang kurang berpihak pada tradisi kultur NU dan tradisi ranah lokal. Di sini terjadi tarik menarik pemahaman baru misalnya tentang menentukan hari untuk usaha, hari perkawinan, bamandimandi untuk perkawinan, menentukan hitungan pada nama anak, soal baik buruk pekerjaan.

4. Masyarakat Banjar masih mengikuti kepada nasehat dan fatwa kiyai NU terhadap persoalan umum keagamaan seperti masalah-masalah keilmuan yang bersifat mistik, hukum Islam, soal perbankan; riba, bisnis, perkawinan, kelahiran anak, kewarisan, menentukan arah kiblat salat, pembangunan mesjid, dll.

5. Kiyai NU adalah kiyai yang memiliki kemampuan ilmu lahir dan batin, baik ilmu agama, tasawuf maupun ilmu gaib.

6. Masyarakat Banjar masih mengakui bahwa untuk memperdalam ilmu agama secara tuntas hanya dapat dilakukan dengan kiyai NU melewati pasantren. Hal ini dibuktikan dengan masih banyaknya antusias masyarakat untuk menyekolahkan anak mereka ke pasantren meskipun diukur persentasi dari jumlah penduduk dirasakan berkurang jauh dari dekati tahun 70-an.

7. Gerakan NU sebagai organisasi yang bergerak dengan semangat harakatul diniyah (gerakan keagamaan), harakatul adabiyah (gerakan moral) maupun sebagai organisasi besar; harakatul ijtimaiyyah (gerakan keorgani- 
sasian), dengan paham ahlus sunnah wal jamaah cukup dominan hanya pada daerah pedesaan-banua lima. Padahal sebelum tahun 90-an cukup dominan di perkotaan; Banjarmasin.

8. Pengurus organisasi NU bukan lagi harus kiyai pasantren tetapi boleh orang biasa. Karenanya nasehat dan fatwa kiyai NU di pasantren akan diikuti sedangkan jika dari pengurus organisasi NU tidak harus diikuti sebab mereka belum dianggap sebagai kiyai NU.

9. Nara sumber ceramah agama yang dilakukan oleh masyarakat Banjar tidak lagi harus orang pasantren atau kiyai NU. Siapapun boleh asalkan ia mampu memberi pengetahuan keagamaan. Ini jelas bahwa perkembangan gerakan keagamaan sekarang dan lazimnya di berbagai tempat di Indonesia, NU dalam gerakan keagamaannya sekarang di kal-sel tidak lagi mampu mendominasi dakwahnya terhadap masyarakat perkotaan (Banjarmasin). Meskipun untuk wilayah pedesaan masih cukup dominan. Kaum muda Islam mulai tertarik dengan usatadz-ustadz muda di luar pasantrent tanpa memperhatikan apakah mereka adalah orang NU ataukah campuran (mungkin lulusan IAIN ?) atau beraliran tidak berpihak pada tradisi kultul NU. Karena mereka masih dianggap dapat menjelaskan bagi eksoteris keagamaan dan pengetahuan prioritas Islam.[] 
Abdul Haris, dkk, Pergeseran Perilaku Politik Kultural Nahdlatul Ulama (NU) di Era Multi Partai Pasca Orde Baru, Studi Kasus NU Jember, Jawa Timur, STAIN Jember Jawa Timur

Alfani Daud, Islam dan Masyarakat Banjar, Rajawali Pers. Jakarta, 1997, h. 5

Amin Rais, Ed, Islam di Indonesia, Rajawali Pers, Jakarta, 1986

Atho' Mudzhar, Gerakan Islam Liberal di Indonesia, artikel Balitbang Depag.RI, Rabu, 12 Maret 2008

Kuntowijoyo, Paradigma Islam, Interpretasi untuk Aksi, Mizan, Jakarta, 1993
Laode Ida, NU Muda; Kaum Progresif dan Sekularisme Baru, Erlangga, Jakarta, 2004

M. Dawan Rahardjo, Intelektual Intelegensia dan Prilaku Politik Bangsa, Mizan, Jakarta, 1993

Nurcholish Madjid, Islam Doktrin dan Peradaban, Paramadina, Jakarta, 1992

Nurcholish Madjid, Islam Kemoderenan dan Keindonesiaan, Mizan, Jakarta, Cet.VI. 1994

Nurcholish Madjid, Islam Kerakyatan dan Keindonesiaan, Mizan, Jakarta, 1993 